\title{
Fungi isolated from maize (Zea mays L.) grain in Lithuania
}

\author{
Aurimas Krasauskas \\ Aleksandras Stulginskis University, \\ Studentu St. 11, \\ 53361 Akademija, \\ Kaunas District, Lithuania \\ Email: Aurimas.Krasauskas@asu.lt
}

\begin{abstract}
The aim of this work was to investigate contamination levels of maize grain by fungi propagules and composition of fungi species. The objects of investigation were maize grain taken in Lithuania, 5 different fields of private farms in the Vilkaviškis District, in 2016 and 2017. Grain samples were taken directly from the field before harvesting at the end of October (Phenological growth stage BBCH 97). Moisture of the samples was measured by a mobile hygrometer Wile 55 . Quantitative grain contamination by fungal propagules (fungal propagules $=\mathrm{cfu}=$ colony forming unit) was determined by a dilution method. Serial decimal dilutions up to $10^{-3}$ were made and $0.1 \mathrm{ml}$ aliquots were inoculated in triplicate onto the Sabouraud glucose agar medium with chloramfenicol $\left(0.5 \mathrm{~g} \mathrm{l}^{-1}\right)$. Results of this study showed that the moisture content in the grain varied from 21.5 to $32.3 \%$. Due to late ripening and unfavourable meteorological conditions the contamination of grain by fungi propagules ranged from 9.5 to $33.2 \mathrm{cfu} \mathrm{g}^{-3}$. Fungi were identified according to morphological and microscopic characteristics. A total of 8 different fungal genera (Absidia spp., Aspergillus spp. Alternaria spp., Cladosporium spp., Epicoccum spp., Fusarium spp., Mortierella spp., Penicillium spp.) and 14 species were identified in total. Fungi of Alternaria and Fusarium genera were prevailing.
\end{abstract}

Keywords: maize, grain, fungi, contamination, mycotoxins

\section{INTRODUCTION}

Maize (Zea mays L.) is one of the most important sources of food for human and animal nutrition and raw materials for industrial processing. The nutritional value of maize grain could vary significantly due to the interaction between the physical, chemical and biological factors (Pechanova, Pechan, 2015). Due to this maize is very convenient for the growth of various microorganisms, first of all, different fungi. These mold fungi have undesirable and measurable effects on grain quality like discolouration, reduced germination, heating, mustiness, sour odours, chemi- cal changes, loss of weight, reduction in grade and mycotoxin contamination (Logrieco et al., 2002; Kedera et al., 1999). The colour and form changes, detectable visually, are actually preceded by chemical changes in the grain caused by the fungi. For example, Aspergillus flavus initially infects the oil-rich germ using grain lipids for its growth and metabolism, and thus lipid hydrolysis takes place faster than the degradation of protein or starch in stored grain (Wacowicz, 1991; Pomeranz, 1992). The contamination of maize with fungi (moulds) and their metabolites mycotoxins represents a major problem for its use in human and animal nutrition (Krnjaja et al., 
2013). It has been reported that the found fungi in maize belong to the genera Talaromyces, Stenocarpella, Penicillium, Phlebiopsis, Cladosporium, Alternaria, Epicoccum, Trichoderma, Aspergillus, Irpex, Fusarium, Microdochium, Mucor and Sarocladium (Camila et al., 2015; Bockus et al., 2010; White 1999). Also Smart et al., 1990 and Munkvold et al., 1997 found that more common species of kernel-rotting fungi (e.g. Fusarium verticillioides, Fusarium graminearum, Diplodia maydis, Trichoderma viride, Nigrospora oryzae, Penicillium oxalicum, etc.) may enter the seed proper based on a different pathology and in earlier stages of kernel development, producing different symptoms of kernel infection. Furthermore, it has been reported that the main fungal species associated with maize grain are Aspergillus flavus, Fusarium verticillioides as well as $F$. proliferatum and F. graminearum, which are known to produce mycotoxins, i.e. aflatoxins, fumonisins, trichothecene and zearalenone (Goswami, Kistler, 2004). Moreover, from some reports (Herteg et al., 2016; Yassin et al., 2011) it was concluded that maize grain are vulnerable to attack by several genera of fungi such as Fusarium, Aspergillus, Penicillium and Helminthosporium from ripening, through harvest and storage. Milevoj and Maček (1985) found that Fusarium culmorum was the most fungus attacked maize ear under field conditions or during inadequate storage conditions, then $F$. moniliforme, and F. oxysporiuim. It has been reported that 81 isolates of Fusarium spp. isolated in different years from naturally contaminated maize ears in 5 different geographic areas (Logrieco et al., 2002; Yli-Mattila, T. 2010). Meanwhile, in the genus Fusarium, the species $F$. verticillioides was predominant and this genus presented the highest diversity, followed by the genera Aspergillus (Camila et al., 2015).

However, it was mentioned that the relative abundance of these fungi differed between years. There was a greater incidence of the Aspergillus fungi group in the dry and higher temperature conditions (Richard, Payne, 2003). Although A. flavus may occur at pre- and/or post-harvest, the amount of produced aflatoxins increase during grain drying and storage phases is poorly managed (Wilson et al., 2004).

These fungi, that play an important role in deterioration of grain, can be divided into field and storage fungi. Yassin et al. (2011) mentioned that the most storage moulds of corn were Fusarium, Penicillium, Aspergillus, and Cladosporium. It has been reported that the most frequent and virulent fungi in stored maize grain were Fusarium moniliforme and Aspergillus flavus (Wilson et al., 2004). Based on their occurrence and moisture content of grain, field fungi are those that contaminate or invade grain in the field, often during or after ripening, and during harvesting operations. Fungi of the Alternaria and Fusarium genera are most frequent on various grain in fields. They perish if the humidity of the nutritious substrate does not exceed 12-13\% (water activity, $\mathrm{aw}=0.65)$ for a longer period of time.

These fungi can reduce the yield, quality, and nutritional value of the grain, while also contaminating it with mycotoxins because of their deleterious biological effects in animals and humans (Richard, Payne, 2003). In many European countries of temperate climate, contamination of grain with the above-mentioned fungi reaches $100 \%$ at the moment of harvesting. Fusarium species have been reported as the most toxigenic fungi in northern temperate regions (Salas et al., 1999). In northern areas a risk will be new toxigenic Fusarium species spreading to the north due to higher temperatures and the increased use of alternative hosts, such as maize. Fusarium species are the most important phytopathogenic and toxigenic fungi in Nordic countries and globally. Several Fusarium species are involved in Fusarium head blight (FHB), which reduces both yield and quality in cereal crops (Bottalico, Perrone, 2002; Yli-Mattila, 2010). Mycotoxin contamination of grain can result in substantial economic losses to maize growers, livestock and poultry producers, grain handlers, and food and feed processors. Fungal-damaged kernels are of low quality and may have undesirable traits besides containing mycotoxins, and the overall corn quality may be improved further by removing all fungal-damaged kernels through optical sorting. But it has been shown that grain cleaning only will not greatly reduce aflatoxin or fumonisin levels in commercially harvested corn (Pearson et al., 2004).

Therefore, the lot or grain produced in Lithuania or brought from abroad should be investigated in order to evaluate its mycological condition, 
to determine what species of fungi propagules the grain is contaminated with and to investigate if the isolated species of fungi are not potential producers of toxins (Lugauskas et al., 1999).

The aim of this investigation was to evaluate contamination levels of maize grain grown in Lithuania by fungi propagules and composition of fungi species.

\section{MATERIALS AND METHODS}

The objects of investigation were maize grain taken in 5 different fields of private Lithuanian farms in 2016 and 2017. Grain samples were taken directly from the fields before harvesting, at the end of October (Phenological growth stage $\mathrm{BBCH}$ 97). The samples of grain were taken in each field in 5 randomly selected plots with four replicates. Moisture of the samples was measured by a mobile hygrometer Wile 55. Quantitative grain contamination by fungal propagules (as total colony-forming units (cfu) per gram) was determined by a dilution method. Serial decimal dilutions up to $10^{-3}$ were made and $0.1 \mathrm{ml}$ aliquots were inoculated in triplicate onto the Sabouraud glucose agar medium with chloramfenicol $\left(0.5 \mathrm{~g} \mathrm{l}^{-1}\right)$ in Petri dishes. The dishes were kept in a thermostat Incucell LSIS at $26 \pm 2^{\circ} \mathrm{C}$ temperature. The growing colonies of fungi were counted on days 3,5 and 7. Fungi were identified according to morphological and microscopic characteristics (Leslie, Summerell, 2006; Pitt, Hocking, 1999; Watanabe, 2002; Nelson, Tous- soun, Marasas, 2006). A DM750 optical microscope system with an ICC50 HD camera from Leica Microsystems for the microscopic pictures taking was used.

In 2016, the thermal conditions of the growing season of crops were closer to the multiannual average, but May and June were warmer (Fig. 1). The average monthly temperature of May was by $3.4^{\circ} \mathrm{C}$ higher than the multiannual average and that of June by $1.6^{\circ} \mathrm{C}$. Moreover, in 2016 it was wetter as usual (Fig. 2). Only May and September were more arid; however, there was an excess of moisture in the summer. July was particularly wet, with rainfall amounting to $160 \mathrm{~mm}$, which was nearly twice as much as the normal rate. September was warm and dry, but October was cool and rainy.

In 2017 the average temperature of April was even by $1.4^{\circ} \mathrm{C}$ below the multiannual. The average monthly rainfall was $43.4 \mathrm{~mm}$ and significantly exceeded the multiannual amount of precipitation. The average temperature of May, like the multiannual, was $12.1^{\circ} \mathrm{C}$, but the precipitation was only $5.8 \mathrm{~mm}$, which is even by $48.2 \mathrm{~mm}$ less compared to the multiannual rainfall. The weather of June was fairly constant. The average temperature of this month was $14.6^{\circ} \mathrm{C}-$ only by $0.3^{\circ} \mathrm{C}$ below the multiannual. The monthly rainfall was by $5.2 \mathrm{~mm}$ above the multiannual average. The average temperature of July was lower than $1.5^{\circ} \mathrm{C}$ compared to the multiannual. Moreover, the average amount of precipitation was even by $103 \mathrm{~mm}$ higher than the multiannual rainfall amount.

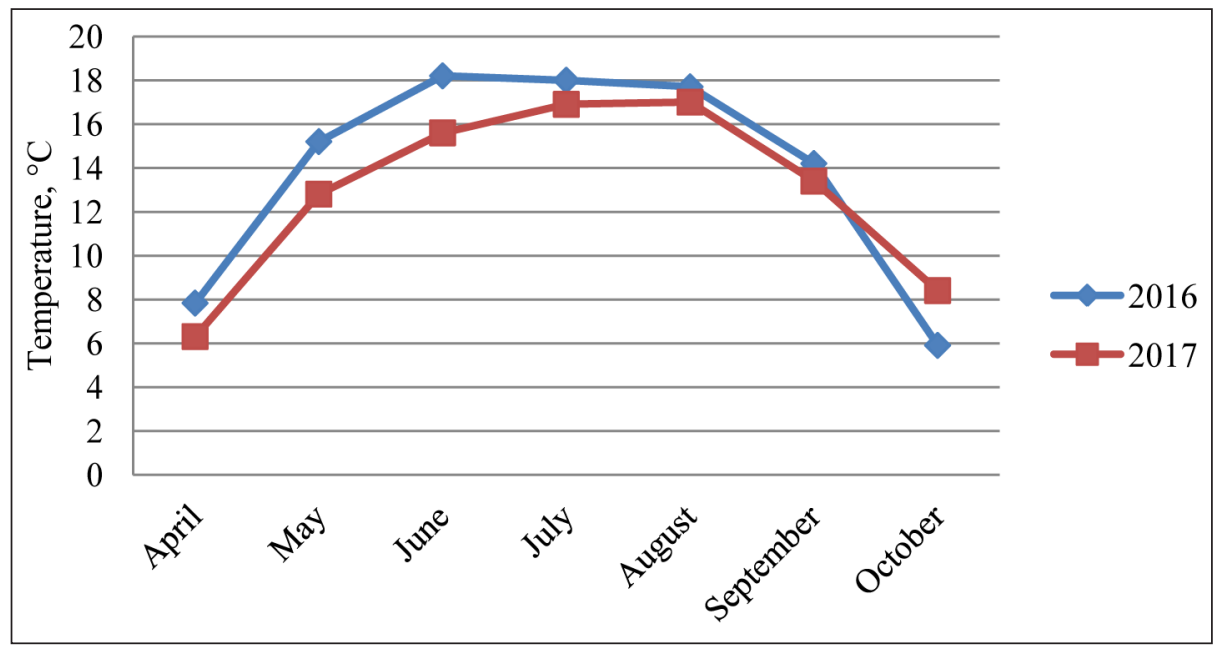

Fig. 1. Average monthly air temperature during the maize growth period 


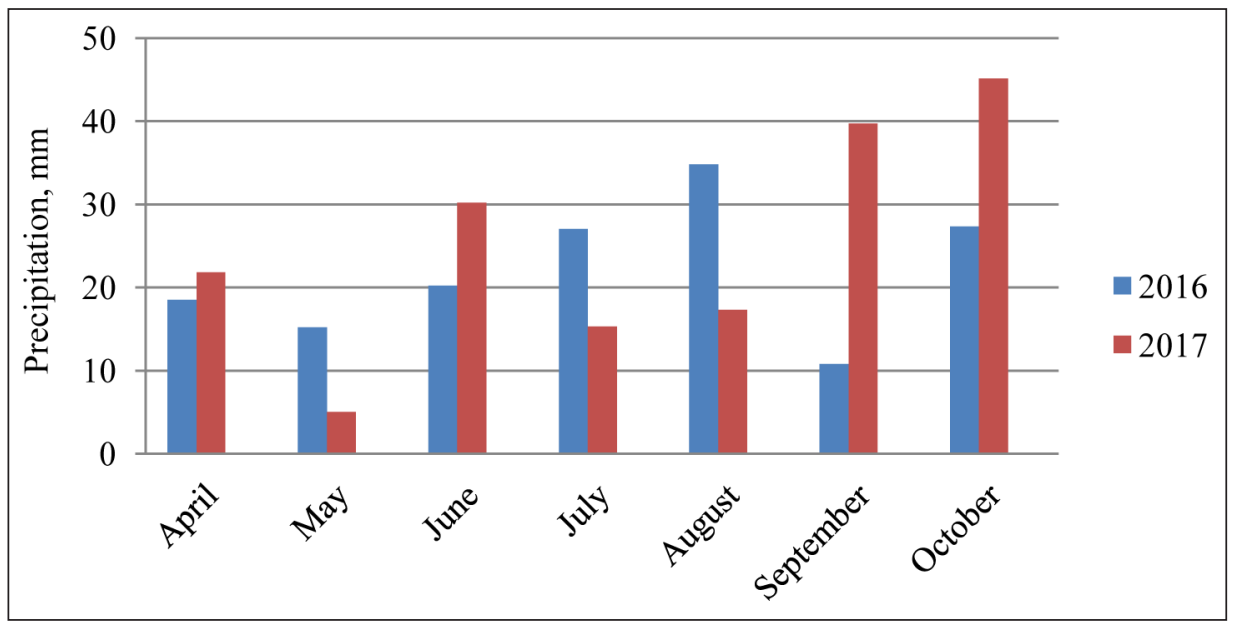

Fig. 2. Average monthly precipitation during the maize growth period

The average temperature of August was only $0.1^{\circ} \mathrm{C}$ higher than the multiannual. The monthly rainfall amount was $58.2 \mathrm{~mm}$, which is $17.8 \mathrm{~mm}$ less compared to the multiannual rainfall. In September the most precipitation dropped in the second decade $-60.3 \mathrm{~mm}$, and in the Monte $-115.0 \mathrm{~mm}$. The multiannual average exceeded $55 \mathrm{~mm}$.

Statistical analysis of the experimental data was done using the software STATISTICA 10. Significance of differences was estimated using the Fisher least significant difference (LSD) test $(p \leq 0.05)$ criterion.

\section{RESULTS AND DISCUSSION}

Maize (Zea mays L.) along with rice and wheat are the three most important stable food grain all over the world for human and animal consumption. In recent years some Lithuanian farmers sow fast ripening breeds of maize and their hybrids trying to grow them under local conditions in order to obtain corn as animal feed rich in albumins. However, the meteorological conditions for maize growing are not always favourable in Lithuania. Such factors as the geographical area and harvest season, drastic oscillations in rainfall, and humidity near harvest are very important in agriculture. In recent years, periods of high relative humidity near harvest-time and delayed harvesting have made a serious problem. An early onset of autumn sometimes stops maturation of maize corn cobs and they may be covered with snow while still in the fields. When the frozen corn were brought into storehouses, an intense development of different fungi was observed. The year 2017 was especially unfavourable for maize maturation. The annual precipitation in 2017 was higher than the standard climate rate of $174 \mathrm{~mm}$, and even higher than the average value of $116 \mathrm{~mm}$ in 2016 .

The highest moisture content was observed in the maize grain samples taken in 2017 - 32.3\%, while almost one third less in the 2016 year samples $-21.5 \%$ (Table 1). Such moisture levels are too high and not incompatible with safe storage even for a short time. The grain needed to be dried up to the optimum moisture content of under $15 \%$ on the average.

Under humid conditions maize grain are susceptible to molding and rapid deterioration. Therefore, they must be dried to safe moisture levels that inhibit the activity of fungi. The grain drying process suppresses the development of fungi, and their vegetative parts are usually destroyed. But fungi spores, such as conidia, being well protected against exterior factors, survive. However, the drying process is usually quite slow. Meanwhile Lugauskas et al. (1999) reported that when various grain samples were collected from different places of the receptacle (from the top of the corn heap, the middle and at discharge opening), it turned out that the number of the fungi did not decrease in the course of drying - moreover, it even slightly increased.

The degree of fungi contamination of grain can be used as a measure of their quality, i.e. grains with low mould counts $\left(10^{1}-10^{3} \mathrm{cfu} / \mathrm{g}\right.$ of samples) are of higher quality and safer than those 
Table. Moisture and contamination levels by fungi of maize grain samples

\begin{tabular}{c|c|c|c|c}
\hline $\begin{array}{c}\text { Year of grain } \\
\text { samples taken }\end{array}$ & $\begin{array}{c}\text { Grain moisture, } \\
\mathbf{\%}\end{array}$ & $\begin{array}{c}\text { Number of isolated } \\
\text { fungi species }\end{array}$ & $\begin{array}{c}\text { Contamination, } \\
\mathbf{c f u ~}^{\mathbf{3}}\end{array}$ & $\begin{array}{c}\text { Prevailing species of fungi } \\
\text { (IF }>\mathbf{4 0 \%})\end{array}$ \\
\hline 2016 & $22.04 \pm 0.4^{\mathrm{a}^{*}}$ & 11 & $12.12 \pm 1.7^{\mathrm{a}}$ & $\begin{array}{c}\text { Cladosporium herbarum } \\
\text { Fusarium moniliforme }\end{array}$ \\
\hline 2017 & $31.17 \pm 0.9^{\mathrm{b}}$ & 8 & $30.24 \pm 2.2^{\mathrm{b}}$ & $\begin{array}{c}\text { Alternaria alternata } \\
\text { Fusarium moniliforme }\end{array}$ \\
\hline
\end{tabular}

* Significant differences $(p<0.05)$ among the years in the column are marked by different letters.

having a higher fungi count $\left(10^{4}-10^{6} \mathrm{cfu} / \mathrm{g}\right.$ of samples), as shown in the study by Karunaratne and Bullerman (1990). The highest counts were detected in the maize grain of the 2017 samples and the lowest ones were found in the 2016 grain samples. The counts of fungi propagules ranged between $9.5-14.8 \mathrm{cfu} \mathrm{g}^{-3}$ in the 2016 year grain samples (Table). The number of fungi propagules was higher in the 2017 year grain samples, possibly because of the late harvest time and heavy rainfall in the summer and autumn periods. The total counts of fungi fluctuated between 27.0 to $33.2 \mathrm{cfu} \mathrm{g}^{-3}$ in the samples of this year.

The mycobiota of the tested maize grain presented different fungi, with different frequencies and percentages, some with the ability to produce mycotoxins. The results of mycological tests indicated that maize were strongly contaminated with fungi propagules - by $73.0 \%$ in the 2016 samples and $90.5 \%$ in the 2017 grain samples, respectively. The found fungi belong to 8 genera (Absidia spp., Aspergillus spp., Alternaria spp., Cladosporium spp., Epicoccum spp., Fusarium spp., Mortierella spp., Penicillium spp.), and 14 species were isolated and identified (Table).

The greatest diversity of fungi species was detected in the grain samples of 2016. The following fungi species were isolated from the maize grain: Absidia spinosa, Alternaria alternata, Aspergillus flavus, Cladosporium herbarum, Epicoccum nigrum, Fusarium moniliforme, F. poae, F. culmorum, Mortierella elongata, $P$. expansum and Penicillium spp. The most frequent and prevalent fungi were Fusarium moniliforme and Cladosporium herbarum (Fig. 3). Alternaria alternata was the dominant species together with Fusarium moniliforme in the grain samples of 2017. Moreover, it was the third most diverse fungus in the maize grain samples in total. The abovementioned species of fungi were accompanied by
Cladosporium herbarum, Fusarium avenaceum, F. equiseti, F. poae, F. sporotrichioides and Penicillium spp.

Grain contamination with field fungi is usually an inevitable consequence of meteorological conditions. According to Richard and Payne (2003), toxin production by some of them has now become of major importance in human and animal diseases because of the direct toxicity and longterm carcinogenic effect. Mycotoxins are natural contaminants of cereals and occur worldwide, even though there are geographic and climatic differences in the amounts produced and occurrence. Greater numbers of species which contaminate maize grain and may produce mycotoxins belong to Aspergillus, Fusarium and Penicillium species (Herteg et al., 2016). As mentioned previously, the greatest number of species found in grain was related to the genus Fusarium representing F. avenaceum, F. culmorum, F. equiseti, F. moniliforme, F. poae and F. sporotrichioides. The species F. moniliforme was predominant fusaria both in the 2016 and 2017 grain samples. According to Nelson, Toussoun and Marasas (2006), F. moniliforme is the accepted species, which was also known as $F$. verticillioides. As referred earlier (Bottalico, Perrone, 2002; YliMattila, 2010; Salas et al., 1999), Fusarium species have been reported as the most toxigenic fungi in northern temperate regions. They are traditionally associated with temperate climatic conditions, since they require lower temperature for growth and mycotoxin production than, for example, the Aspergillus species. The most toxicologically important Fusarium mycotoxins are trichothecenes (including deoxynivalenol (DON) and T-2 toxin (T-2)), zearalenone (ZEN) and fumonisin B1 (FB1). The results of this research illustrate the potential danger that maize corn contaminated or damaged by fungi in grain may cause. 

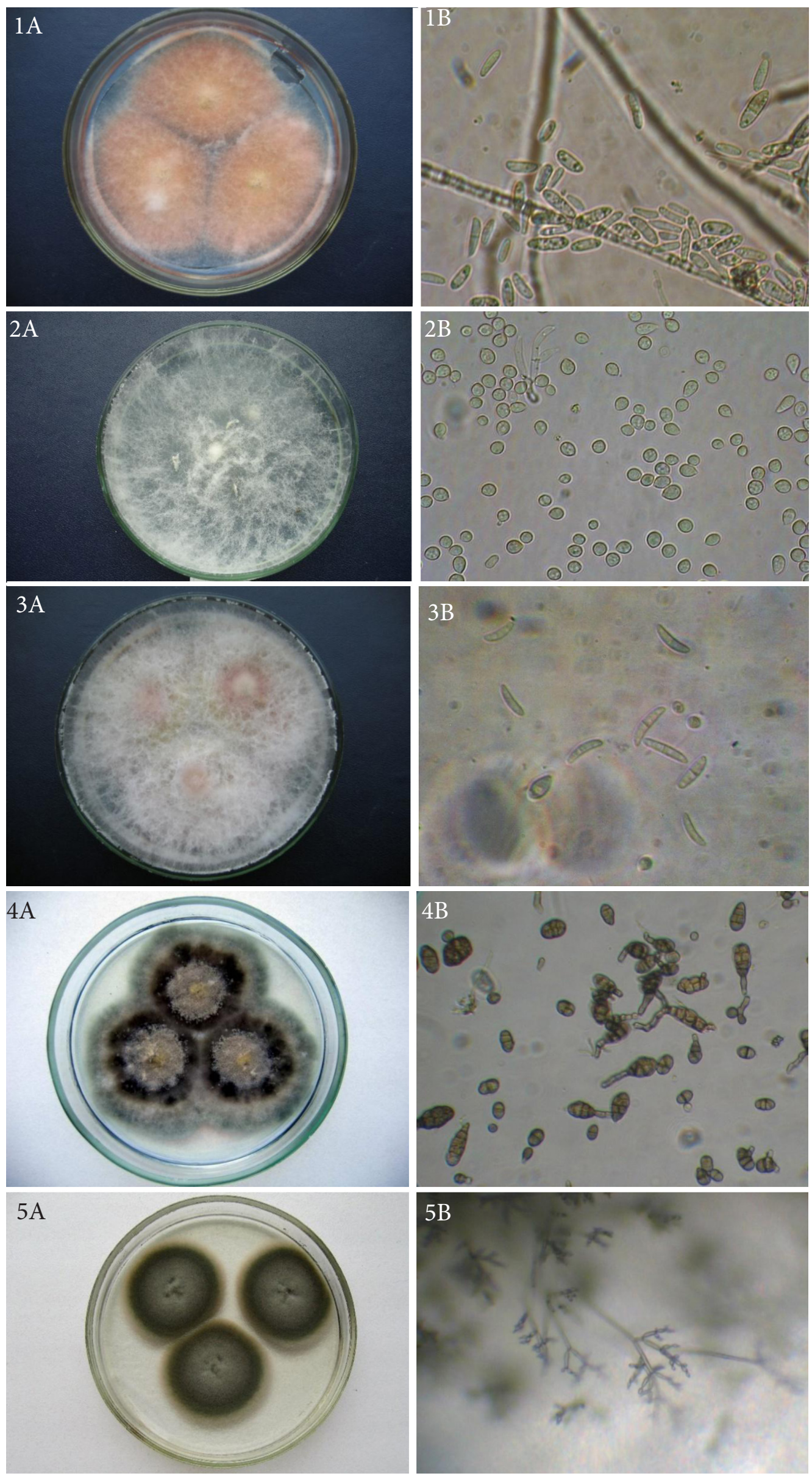

Fig. 3. Field fungi colonies (A) and conidia (B) on Sabouraud glucose agar:

Fusarium moniliforme (1); Fusarium poae (2);

Fusarium sprot-

richioides (3);

Alternaria alternata (4);

Cladosporium herbarum (5) 
The task of reducing maize contamination with fungi in fields and preparing fast drying technologies for grain is of great importance, upon which rests the success of a newly invented technical equipment.

\section{CONCLUSIONS}

1. The highest moisture content (32.3\%) was observed in the maize grain samples taken in 2017, while almost one third less in the 2016 year samples $-21.5 \%$. Meteorological conditions for maize harvesting were not favourable in 2017.

2. The counts of fungi propagules ranged from 9.5 to $14.8 \mathrm{cfu} \mathrm{g}^{-3}$ in the 2016 samples and from 27.0 and $33.2 \mathrm{cfu} \mathrm{g}^{-3}$ in the 2017 grain samples. The number of fungi propagules was higher in the 2017 year grain samples, because of the late harvest time and heavy rainfall in the summer and autumn periods.

3. A total of 8 different fungal genera (Absidia spp., Aspergillus spp. Alternaria spp., Cladosporium spp., Epicoccum spp., Fusarium spp., Mortierella spp., Penicillium spp.) and 14 species were isolated from the grain. The fungi of Alternaria and Fusarium genera were prevailing and can be regarded as potential producers of mycotoxins.

Received 17 August 2018 Accepted 12 December 2018

\section{REFERENCES}

1. Bockus W. W., Bowden R. L., Hunger R. M., Morrill W. L., Murray T. D., Smiley R. W. (eds.). 2010. Compendium of Wheat Diseases and Pests. 3rd edn. St Paul, MN: American Phytopathological Society. $171 \mathrm{p}$.

2. Camila A., Carla B., Fernandes C., Sandra R., Souza F., Cleiltan N., Dauri J., Ione P. 2015. Fungi isolated from maize (Zea mays L.) grains and production of associated enzyme activities. International Journal of Molecular Sciences. Vol. 16. P. 1538-1536.

3. Goswami R., Kistler C. 2004. Heading for disaster: Fusarium graminearum on cereal crops. Molecular Plant Pathology. Vol. 5(6). P. 515-525.

4. Herteg D., Matyus A., Drienovski R., Cotuna O., Pop G. 2016. Study regarding the identification of mycotoxigenous fungi from the seed mass of maize. Research Journal of Agricultural Science. Vol. 48(4). P. 212-218.

5. Karunaratne A., Bullerman L. B. 1990. Interactive effects of spore load and temperature on aflatoxin production. Journal of Food Protection. Vol. 53. No. 3. 227-229.

6. Kedera C. J., Leslie J. F., Claflin L. E. 1999. Systemic infection of corn by Fusarium moniliforme. Phytopathology. Vol. 82. P. 1138-1145.

7. Krnjaja V., Levic J., Stankovic S., Petrovic T., Tomic Z., Mandic V., Bijelic Z. 2013. Moulds and mycotoxins in stored maize grains. Biotechnology in Animal Husbandry. Vol. 29(3). P. 527-536.

8. Leslie J. F., Summerell B. A. 2006. The Fusarium Laboratory Manual. Iowa: Blackwell Publishing. $320 \mathrm{p}$.

9. Logrieco A., Mulè G., Moretti A., Bottalico A. 2002. Toxigenic Fusarium species and mycotoxins associated with maize ear rot in Europe. European Journal of Plant Pathology. Vol. 108. P. 597-609.

10. Lugauskas A., Repečkienė J., Krasauskas A., Zvicevičius E. 1999. Micromycetes affecting nuts, maize and barley used for food and animal feed. Botanica Lithuanica. Vol. 5(2). P. 165-170.

11. Milevoj M. L., Maček J. 1985. Plesnivost storžev koruze v sloveniji. Agronomski glasnik: Glasilo Hrvatskog agronomskog društva. No. 37. P. 1-4.

12. Munkvold G. P., McGee D. C., Carlton W. M. 1997. Importance of different pathways for maize kernel infection by Fusarium moniliforme. Phytopathology. Vol. 87(2). P. 209-217.

13. Nelson E. P., Toussoun A. T., Marasas O. F. 2006. Fusarium Species. An Illustrated Manual for Identification. University Park and London: The Pennsylvania State University Press. 206 p.

14. Pearson T. C., Wicklow D. T., Pasikatan M. C. 2004. Reduction of aflatoxin and fumonisin contamination in yellow corn by high-speed dual-wavelength sorting. Cereal Chemistry. Vol. 81(4). P. 490-498.

15. Pechanova O., Pechan T. 2015. Maize-pathogen interactions: an ongoing combat from a proteomics perspective. International Journal of Molecular Sciences. Vol. 16. P. 28429-28448.

16. Pitt J. I., Hocking A. D. 1999. Fungi and Food Spoilage. 2nd edn. Chapman and Hall. 430 p.

17. Pomeranz Y. 1992. Biochemical, functional, and nutritive changes during storage. In: Storage of Cereal Grains and Their Products. 4th edn. St. Paul, Minn.: American Association of Cereal Chemists. P. 55-141.

18. Richard J. L., Payne G. A. 2003. Mycotoxins: Risks in Plant, Animal, and Human Systems. CAST Task Force Report No. 139. Ames, Iowa: Council for Agricultural Science and Technology.

19. Salas B., Steffenson B. J., Casper H. H., Tacke B., Prom L. K., Jr. Fetch T. G., Schwarz P. B. 1999. Fusarium species pathogenic to barley and their associated mycotoxins. Plant Diseases. No. 83. P. $667-$ 674.

20. Smart M. J., Wicklow D. T., Caldwell R. W. 1990. Pathogenesis in Aspergillus ear rot of maize: 
Light microscopy of fungal spread from wounds. Phytopathology. Vol. 80(12). P. 1287-1294.

21. Wacowicz E. 1991. Changes of chemical grain components, especially lipids, during their deterioration by fungi. In: Cereal Grain: Mycotoxins, Fungi, and Quality in Drying and Storage. Amsterdam, The Netherlands: Elsevier. P. 259-280.

22. Watanabe T. 2002. Pictorial Atlas of Soil and Seed Fungi. Morphologies of Cultured Fungi and Key to Species. 2nd edn. CRC Press LLC. 426 p.

23. Wilson A., Simpson D., Chandler E., Jennings P., Nicholson P. 2004. Development of PCR assays for the detection and differentiation of Fusarium sporotrichioides and Fusarium langsethiae. FEMS Microbiology Letters. Vol. 233. P. 69-76.

24. Yassin M. A., El-Samawaty A. M., Moslem M., Bahkali A., Abd-Elsalam K. 2011. Fungal biota and occurrence of aflatoxigenic Aspergillus in postharvest corn grains. Fresenius Environmental Bulletin. Vol. 20(4). P. 903-909.

25. Yli-Mattila T. 2010. Ecology and evolution of toxigenic Fusarium species in cereals in northern Europe and Asia. Plant Pathology. Vol. 92. P. 7-18.

\section{Aurimas Krasauskas \\ GRYBAI, IŠSKIRTI IŠ LIETUVOJE UŽAUGINTŲ KUKURŪZŲ (ZEA MAYS L.) GRŪDŲ}

Santrauka

Darbo tikslas buvo ištirti kukurūzų grūdų taršą grybų pradais ir grybų rūšinès sudèties ịvairovę Lietuvos klimato sąlygomis. Tyrimo objektas - kukurūzų grūdai, paimti penkiuose skirtinguose Vilkaviškio rajono ūkių laukuose 2016 ir 2017 metais. Grūdų mèginiai iš laukų buvo paimti prieš derliaus nuèmimą (spalio mèn. pabaigoje). Mèginių drègmè išmatuota mobiliu termohigrometru „Wile 55 “. Kiekybinis grūdų užteršimas grybų pradais nustatytas skiedimo metodu ir skiedinių sèjimu trimis pakartojimais ị Saburo gliukozès agaro terpę su chloramfenikolu $\left(0,5 \mathrm{~g} \mathrm{l}^{-1}\right)$. Atlikto tyrimo rezultatai parodè, kad kukurūzų grūdų drègnumas skirtingais tyrimų metais svyravo nuo 21,5 iki 32,3\%. Dèl vèlyvos brandos ir nepalankių meteorologinių sąlygų kukurūzų grūdų tarša grybų pradais siekè nuo $9,5 \mathrm{cfu} / \mathrm{g}^{-3}$ iki $33,2 \mathrm{cfu} / \mathrm{g}^{-3}$. Grybai buvo identifikuoti pagal morfologines ir mikroskopines savybes. Išskirtos aštuonios skirtingų grybų gentys (Absidia spp., Aspergillus spp. Alternaria spp., Cladosporium spp., Epicoccum spp., Fusarium spp., Mortierella spp., Penicillium spp.) ir identifikuota 14 rūšių. Grūduose labiausiai buvo paplitę $A l$ ternaria ir Fusarium genčiu grybai.

Siekiant sumažinti derliaus nuostolius, gauti geresnès kokybès grūdus ir išvengti žmonèms bei gyvūnams keliamo toksinų pavojaus, būtina nustatyti grūdų pažeidejus grybus, ištirti jų ekologinius savitumus, naudoti priemones, ribojančias jų plitimą maisto žaliavose.

Raktažodžiai: kukurūzai, grūdai, mikromicetai, tarša, mikotoksinai 